\title{
Continental Margin Subsidence From Shallow Mantle Convection: Example From West Africa
}

\author{
Bhavik Harish Lodhia ${ }^{1}$, Gareth G. Roberts ${ }^{1}$, Alastair J. Fraser ${ }^{1}$, \\ Stewart Fishwick ${ }^{2}$, Saskia Goes ${ }^{1}$, Jerry Jarvis ${ }^{3}$ \\ ${ }^{1}$ Department of Earth Science and Engineering, Imperial College London, South \\ Kensington Campus, SW72AZ, UK, gareth.roberts@imperial.ac.uk. \\ ${ }^{2}$ Department of Geology, University of Leicester, Leicester, LE1 7RH, UK. \\ ${ }^{3}$ Tullow Oil Plc., Chiswick Park, 566 Chiswick High Road, London, W4 5XT, UK.
}

\section{Abstract}

Spatial and temporal evolution of the uppermost convecting mantle plays an important role in determining histories of magmatism, uplift, subsidence, erosion and deposition of sedimentary rock. Tomographic studies and mantle flow models suggest that changes in lithospheric thickness can focus convection and destabilize plates. Geologic observations that constrain the processes responsible for onset and evolution of shallow mantle convection are sparse. We integrate seismic, well, gravity, magmatic and tomographic information to determine the history of Neogene-Recent (<23 Ma) upper mantle convection from the Cape Verde swell to West Africa. Residual ocean-age depths of $+2 \mathrm{~km}$ and oceanic heat flow anomalies of $+16 \pm 4 \mathrm{~mW} \mathrm{~m}^{-2}$ are centered on Cape Verde. Residual depths decrease eastward to zero at the fringe of the Mauritania basin. Backstripped wells and mapped seismic data show that $0.4-0.8 \mathrm{~km}$ of water-loaded subsidence occurred in a $\sim 500 \times 500 \mathrm{~km}$ region centered on the Mauritania basin during the last $23 \mathrm{Ma}$. Conversion of shear wave velocities into temperature and simple isostatic calculations indicate that asthenospheric temperatures determine bathymetry from Cape Verde to West Africa. Calculated average excess temperatures beneath Cape Verde are $>+100^{\circ} \mathrm{C}$ providing $\sim 10^{3} \mathrm{~m}$ of support. Beneath the Mauritania basin average excess temperatures are $<100^{\circ} \mathrm{C}$ drawing down the lithosphere by $\sim 10^{2}$ to $10^{3} \mathrm{~m}$. Up- and downwelling mantle has generated a bathymetric gradient of $\sim 1 / 300$ at a wavelength of $\sim 10^{3} \mathrm{~km}$ during the last $\sim 23 \mathrm{Ma}$. Our results suggest that asthenospheric flow away from upwelling mantle can generate downwelling drips beneath continental margins. 
Keywords: Small-scale mantle convection, Cape Verde, West Africa, Dynamic support, Uplift, Subsidence

\section{Introduction}

Tomographic studies, magmatic histories and mantle flow models suggest that variations in mantle temperature, lithospheric thickness and plate motion play an important role in generating shallow mantle convection (e.g. Pekeris, 1935; McKenzie et al., 1974; King \& Ritsema, 2000; Moucha and Forte, 2011; Davies \& Rawlinson, 2014; Barnett-Moore et al., 2017; Hoggard et al., 2017; Müller et al., 2017). Constraining scales and evolution of subplate support and its expression at Earth's surface, particularly at passive margins, has important implications for interpretation of stratigraphy, heat flow, glacio-eustasy and for parameterizing models of mantle convection (e.g. Courtney \& White, 1986; Hartley \& Allen, 1994; Flament et al., 2013). We combine seismic reflection and well data along the West African margin with shear wave tomography and the uplift and magmatic history of the Cape Verde Rise to constrain thermal, spatial and temporal scales of upper mantle convection.

It is generally accepted that the mantle beneath the African plate supports short $\left(\sim 10^{3} \mathrm{~km}\right)$ wavelength swells and basins (e.g. Holmes, 1965; Nyblade and Robinson, 1994; Burke, 1996; Crosby \& McKenzie, 2006; Burke \& Gunnell, 2008; Al-Hajri et al., 2009; Jones et al., 2012). Some swells are magmatic (e.g. Afar, Hoggar, Tibesti, Cape Verde), others are amagmatic (e.g. Bié, Fouta Djallon), most have positive free-air gravity anomalies, sit atop slow upper mantle shear-wave velocity anomalies and those intersecting oceanic lithosphere have residual bathymetry of up to $+2 \mathrm{~km}$ (e.g. Courtney \& White, 1986; Lithgow-Bertelloni and Silver, 1998; Pim et al., 2008; Fishwick, 2010; Ramalho et al., 2010; Jones et al., 2012; Ritsema et al., 2012; French et al., 2013; Priestley \& McKenzie, 2013; Shaeffer \& Lebedev, 2013; Hoggard et al., 2017). Drainage networks splay radially from many domal swells suggesting sub-plate support exerts an important control on geomorphology (Paul et al., 2014). In contrast, negative free-air gravity anomalies and ocean-age depth residuals, subsidence patterns and anomalously fast upper mantle shear-wave velocity anomalies indicate some parts of the continent (e.g. Congo basin) are convectively drawn down (e.g. Crosby et al., 2010; Jones et al., 2012; Hoggard et al., 2017). These observations show that 
mantle convection plays an important role in determining vertical motions of African lithosphere.

Continental uplift histories provide information about the timescale of positive sub-plate support. For example, laterites and lateritic gravels indicate that pre-Oligocene topographic gradients in West Africa were low (e.g. Burke and Gunnell, 2008; Chardon et al., 2016). The broadly coeval growth of carbonate reefs on deltas fringing the African continent imply low rates of clastic efflux until $\sim 23 \mathrm{Ma}$ (e.g. Walford et al., 2005; Paul et al., 2014). Uplifted marine terraces, over-compacted stratigraphy, sedimentary flux histories and magmatism indicate post-Oligocene epeirogeny occurred in Africa (e.g. Partridge and Maud, 1987; Walford et al., 2005; Al-Hajri et al., 2009; Guiraud et al., 2010; Rouby et al., 2016). Uplift rate histories calculated by inverting drainage networks indicate that post-35 Ma uplift of topographic swells was diachronous and staged (Paul et al., 2014; Rudge et al., 2015). This work suggests that the landscapes of the African continent are largely Neogene in age and are a result of changing patterns of sub-plate support. If upwelling mantle generated regional uplift we might expect downwelling mantle to have generated broadly coeval regional subsidence patterns.

We examine the history of sub-plate support of the West African margin where hitherto ambiguous Neogene subsidence histories contain important information about thermal and spatial scales of convective drawdown. We first determine the structure of modern lithosphere and the upper mantle using a new shear wave tomographic model and gravity data. We show that uplift and magmatism of the Cape Verde Rise is broadly coeval with rapid Neogene subsidence of the Mauritania margin constrained by well and seismic data. These uplift and subsidence patterns are then combined with temperature and simple isostatic calculations to constrain thermal and spatio-temporal scales of upper mantle convection.

\section{Data Processing and Methodology}

\subsection{Shear wave velocities}

For the mantle structure, we use an updated version of the Rayleigh wave African tomography model from Fishwick (2010), which is probably the highest resolution regional tomography model available. The shear-wave velocity structure is derived by inverting waveforms at periods between 50 and 120 s for the fundamental mode and the first four overtones. The 2010 version of the model was updated to incorporate data from recent deployments. For 
our region of interest, most significant are the inclusion of data from Mid Atlantic Ridge events recorded on the PICASSO (Levander et al., 2009) and Muenster-Morocco (Thomas, 2010) deployments. These provide dense path coverage in northwest Africa. Resolution tests show that velocity perturbations of a few percent at wavelengths $\sim 300 \mathrm{~km}$ are resolvable beneath Cape Verde and the Mauritania basin (Supplementary Information). Figure 2 shows a slice at $125 \mathrm{~km}$ depth through the velocity model for West Africa and its surroundings. Other depth slices are given in Supplementary Figure A.12.

\subsection{Temperature from shear wave velocities and isostasy}

To estimate the thermal state of the mantle beneath West Africa and Cape Verde the new shear wave model was converted into temperature. Look-up charts showing temperature as a function of depth and shear wave velocity $\left(V_{s}\right)$ are shown in Figure 3 for Priestley \& McKenzie (2006)'s empirical parametrization and for Goes et al. (2012)'s mineral physics approach (see Supplementary Information for detailed methodology). The difference between the two parametrizations is also shown. Calculated temperatures differ by $<200^{\circ} \mathrm{C}$ for $V_{s}$ values in this study (i.e. within $0.3 \mathrm{~km} \mathrm{~s}^{-1}$ of AK135: see Figure $3 \mathrm{C}$ ). Figure $3 \mathrm{D}-\mathrm{G}$ shows temperature profiles calculated using the two parametrizations beneath Mauritania and the Cape Verde Rise. Solutions to the analytical expressions in Section 2 of Priestley \& McKenzie (2013) yield a similar lithospheric geotherm to their 2006 parametrization. The isostatic support, $U$, generated by excess asthenospheric temperature, $\bar{T}$, within a layer of thickness $h$ can be calculated using

$$
U=\frac{h \alpha \bar{T}}{1-\alpha T_{\circ}},
$$

where $T_{\circ}$ is the background temperature, which we set to $1330^{\circ} \mathrm{C}$, and $\alpha$ is the thermal expansion coefficient (Rudge et al., 2008). Note that this calculation is insensitive to assumed background temperature because $\alpha \ll 1$. For example, a $100^{\circ} \mathrm{C}$ change in background temperature changes calculated uplift by $\sim 1 \mathrm{~m}$.

\subsection{Ocean age-depth residuals}

Residual ocean-age depth measurements help identify regions supported by sub-plate processes and can test results obtained using Equation 1 (e.g. Richards et al., 2016). The longest seismic line in our inventory extends 
$>400 \mathrm{~km}$ from the West African margin onto the Cape Verde Rise (Figure 4A). The seabed, sediment-basement interface and oceanic Moho are easily identified (Figure 4B). We interpret the prominent intra-crustal impedance contrasts as igneous sills. We use Hoggard et al. (2017)'s sediment and crustal thickness corrections, which incorporate a large amount of seismic data from the Atlantic Ocean, to calculate residual depths from their plate cooling model. Residual depths were measured at the points marked on Figure 4B and are plotted in Figure 1A along with Hoggard et al. (2017)'s compilation. These values are compared to estimates of dynamic topography calculated using long wavelength $(800-2500 \mathrm{~km})$ components of the EIGEN6c GOCE gravity field and an admittance of $35 \pm 10 \mathrm{mGal} \mathrm{km}^{-1}$ (Figure 1; Förste et al., 2014; Hoggard et al., 2017).

\subsection{Subsidence history}

Stratigraphy

To determine the history of sub-plate support we map stratigraphy using an inventory of 8 commercial wells, 1 IODP well and 38 two-dimensional seismic lines on a $10 \times 5 \mathrm{~km}$ grid with record lengths of 8-10 seconds two-way time. The wells are located in the north, center and south of the Mauritanian basin (Figure 1B). They provide biostratigraphic age constraints and standard N and $\mathrm{CN}$ schemes have been used to calibrate the planktonic foraminiferal and calcareous nannoplankton assemblages, respectively. Seven prominent horizons (seabed, 5.6 Ma, 23.8 Ma, 58.4 Ma, 70.4 Ma, 89.4 Ma and basement) have been identified using well and seismic data. Figure $4 \mathrm{C}-\mathrm{D}$ shows the eastern portion of the longest line with a stratigraphic interpretation based on the well and seismic data.

\section{Backstripping for subsidence histories}

The subsidence history of the Mauritania basin was calculated by backstripping the eight wells in our inventory. First, check-shot data from each well were used to determine compaction of sediment as a function of depth, $z$ (Figure 5). Porosity, $\phi$, was parameterized using Athy'17s (1930) formulation,

$$
\phi=\phi_{\circ} \exp \left(-\frac{z}{\lambda}\right)
$$

The initial porosity, $\phi_{\circ}$, and compaction wavelength, $\lambda$, were constrained using a simple empirical relationship between velocity as a function of depth, $v(z)$, and compaction, such that 


$$
\frac{1}{v(z)}=\frac{\phi(z)}{v_{w}}+\frac{1-\phi(z)}{v_{s g}},
$$

where $v_{w}$ is pore fluid velocity and $v_{s g}$ is solid grain velocity (Wyllie et al., 1956). For seawater, $v_{w}=1.5 \mathrm{~km} \mathrm{~s}^{-1}$. We assume that $v_{s g}=5.5 \pm 0.5 \mathrm{~km}$ $\mathrm{s}^{-1}$, which is appropriate for a mixture of sand and clay (Christensen, 1982). Since two-way time, $t=2 \int_{0}^{z} \mathrm{~d} z / v(z)$, we can combine Equations (1) and (2) to obtain

$$
\frac{t}{2}=\frac{z}{v_{s g}}+\phi_{0} \lambda\left(\frac{1}{v_{w}}-\frac{1}{v_{s g}}\right)\left[1-\exp \left(-\frac{z}{\lambda}\right)\right] .
$$

to obtain

$$
z_{4}=z_{2}-z_{1}+\phi_{\circ} \lambda\left[\exp \left(-\frac{z_{2}}{\lambda}\right)+\exp \left(-\frac{z_{1}}{\lambda}\right)+1-\exp \left(-\frac{z_{4}}{\lambda}\right)\right] .
$$

$z_{4}$ is solved by the Newton-Raphson method. We calculate water-loaded subsidence assuming a fixed sea level for each well using a simple isostatic calculation,

$$
S_{w}=S_{s}\left(\frac{\rho_{a}-\rho_{s}}{\rho_{a}-\rho_{w}}\right)+W_{d}
$$

where water loaded subsidence, $S_{w}$, is expressed as a function of sedimentloaded subsidence, $S_{s}$ (Sclater \& Christe, 1980). Asthenospheric density, $\rho_{a}=3200 \mathrm{~kg} \mathrm{~m}^{-3}$, sediment density, $\rho_{s}=2400 \mathrm{~kg} \mathrm{~m}^{-3}$, and density of water, $\rho_{w}=1000 \mathrm{~kg} \mathrm{~m}^{-3}$. We apply paleo-water depth corrections, $W_{d}$, based on benthonic biofacies (e.g foraminifera assemblages) documented in well reports. Table 1 summarizes the paleo-water depth corrections, which are consistent with Vear (2005). Water-loaded subsidence and chronostratigraphy for all wells are shown in Figure 7. 
Theoretical thermal subsidence

We compare measured subsidence patterns to theoretical post-rift (i.e. thermal) subsidence. The thermal subsidence curves, $S_{t}(t)$ in Figure 7 were produced using

$$
S_{t}=E_{\circ} r\left[1-\exp \left(-\frac{t}{\tau}\right)\right]
$$

where

$$
E_{\circ}=\frac{4 l \rho_{m} \alpha T}{\pi^{2}\left(\rho_{m}-\rho_{w}\right)}, \quad r=\frac{\beta}{\pi} \sin \left(\frac{\pi}{\beta}\right) .
$$

Parameters and their values are as follows, $t=$ time, $\tau=$ thermal time constant $=l^{2} / \pi^{2} \kappa$, where $l=$ lithospheric thickness $(125 \mathrm{~km})$, thermal diffusivity, $\kappa=10^{6} \mathrm{~m}^{2} \mathrm{~s}^{-1}$. Mantle density, $\rho_{m}=3300 \mathrm{~kg} \mathrm{~m}^{-3}, \alpha=3.3 \times 1710^{-5} /{ }^{\circ} \mathrm{C}$, and temperature of the asthenosphere $=1330^{\circ} \mathrm{C}$ (Fowler, 2006). We assumed that the end of rifting (i.e. $t=0$ ) occurred at $170 \mathrm{Ma}$ (Vear, 2005). The best-fitting stretching factors, $\beta$, are annotated in Figure 7.

\section{Solid sediment thickness}

We examined the spatial distribution of sedimentary rock across the Mauritania margin using our inventory of reflection seismic lines. First, sedimentary horizons were mapped in two-way time, $t$. Secondly, check shot data from all wells were stacked and averaged to determine the best-fitting regional velocity model: $z(t)=0.0017 t^{2}+0.9 t-34$ where $t=$ two-way travel time in ms. This model was used to calculate the depth of each horizon and solid sediment thickness, $T_{\text {sol }}$, between seismic horizons (e.g. seabed, 5.6 Ma, 23.8 Ma; Figure 4) was calculated using

$$
T_{\text {sol }}=z_{2}-z_{1}+\phi_{\circ} \lambda\left[\exp \left(-\frac{z_{2}}{\lambda}\right)-\exp \left(-\frac{z_{1}}{\lambda}\right)\right],
$$

which corrects for the effects of compaction. We used the compaction parameters, $\phi_{\circ}=0.75 \pm 0.1, \lambda=2.66 \pm 1.2 \mathrm{~km}$, that best-fit the mean time-depth pairs of all check shot data in our inventory (Figure 5). $z_{1}$ and $z_{2}$ are depth of the top and bottom of a seismic interval, respectively (e.g. Walford et al., 2005). Solid sediment thickness of Neogene rock is shown in Figure 8. 


\section{Results}

\subsection{Tomography}

The Mauritania margin sits between the Cape Verde swell and the West African Craton. The Cape Verde swell is underlain by slow mantle $\left(V_{s}<4.4\right.$ $\mathrm{km} \mathrm{s}^{-1}$ ) between 75 and $200 \mathrm{~km}$ depth (Figure $2 \&$ Supplementary Figure A.12). A protuberance of fast velocities $\left(V_{s}>4.4 \mathrm{~km} \mathrm{~s}^{-1}\right)$ extends from the West African Craton beneath the Mauritania margin between $\sim 100$ and $150 \mathrm{~km}$ depth (see Supplementary Information). This protuberance extends beneath the stretched lithosphere of the West African margin, and is located beneath the central portion of the Mauritania basin (the region covered by the wells in our inventory). Two receiver function studies from Cape Verde have shear wave velocities that differ by $>0.5 \mathrm{~km} \mathrm{~s}^{-1}$ at depths $<100 \mathrm{~km}$, which makes them difficult to interpret (cf. Lodge \& Helfrich 2006; Vinnik et al., 2012). Vinnik et al. (2012)'s study indicates that shear wave velocities are up to $0.4 \mathrm{~km} \mathrm{~s}^{-1}$ slower than AK135 at depths of 100-200 km, which is broadly similar to the velocity structure in our regional tomographic model.

\subsection{Temperature from shear wave velocities}

The $1330^{\circ} \mathrm{C}$ isotherm calculated using Priestley \& McKenzie (2006)'s and Goes et al. (2012)'s parametrizations is at a depth of 90-105 km beneath Cape Verde and 145-175 km beneath the Mauritania basin (Figure 9c). Conversion of shear wave velocities into temperature yield average values of $1486 \pm 26^{\circ} \mathrm{C}$ and $1248 \pm 34^{\circ} \mathrm{C}$ for a $100-200 \mathrm{~km}$ deep layer beneath the Cape Verde Rise and Mauritania basin, respectively. The uncertainties in calculated temperatures encapsulate the range of values determined from the Priestley \& McKenzie (2006) and Goes et al. (2012) parametrizations. Uncertainties in temperatures from $V_{s}$ based on uncertainties in experimental elastic and anelastic parameter values have been estimated to be about $50^{\circ} \mathrm{C}$ (Cammarano et al. 2003). Using a simple isostatic relationship between excess temperature of the layer and uplift yields $+643 \pm 88 \mathrm{~m}$ for the Cape Verde Rise and $-180 \pm 114 \mathrm{~m}$ for the Mauritania basin (Equation 1). Calculated temperature (and isostatic support) depends strongly on the data distribution and inversion method used to derive the shear velocity model. For example, isostatic support of Cape Verde and the Mauritania basin calculated using Schaeffer \& Lebedev (2013)'s shear wave model are $+466 \pm 20$ $\mathrm{m}$ and $-827 \pm 16 \mathrm{~m}$, respectively. These calculations indicate that a change 
in sub-plate support of order $+10^{3} \mathrm{~m}$ to $-1710^{3} \mathrm{~m}$ exists from Cape Verde to West Africa.

\subsection{Ocean age-depth}

Residual ocean-age depths decrease from $+1.5 \pm 0.5 \mathrm{~km}$ on the Cape Verde Rise eastward to $0 \mathrm{~km}$ where oceanic lithosphere abuts the Mauritania margin (Figure 1). These observations are consistent with Courtney \& White's (1986) heat flow anomalies, which decrease to normal oceanic values from $+16 \pm 4 \mathrm{~mW} \mathrm{~m}^{-2}$ at the center of rise. The change in residual depth anomalies is coincident with an increase in shear wave speeds from $<4.2 \mathrm{~km} \mathrm{~s}^{-1}$ beneath the Cape Verde Rise to $>4.4 \mathrm{~km} \mathrm{~s}^{-1}$ beneath the Mauritania basin (Figure 2).

\subsection{Stratigraphy and subsidence}

There is at least $8 \mathrm{~km}$ of Cenozoic and Mesozoic sedimentary rock in the Mauritania basin. Paleocene-Eocene stratigraphy is characterized by low rates of clastic deposition. Apart from the northernmost part of the study area, Eocene to Late Oligocene stratigraphy is dominated by extensive carbonate deposition. Proximal sedimentary rock has been eroded, which was probably caused by Oligocene-Neogene uplift and erosion of continental topography (e.g. Rudge et al., 2015; Chardon et al., 2016). This denudation is most clearly expressed at well Chinguetti 4-3 where Miocene stratigraphy $(\sim 23 \mathrm{Ma})$ is underlain by a prominent regional unconformity that marks a significant change from carbonate to clastic input (Figure 4). Foraminiferal assemblages indicate that Cenozoic paleo-water depth was neritic $(0-150 \mathrm{~m})$ at proximal wells and middle bathyal (500-2000 m) at distal wells (Table 1; Figure 7; Leckie \& Olson, 2003; Vear, 2005; Immenhauser, 2009). The foraminiferal data indicate that dramatic Neogene changes in water depth did not occur, which could be a result of high sedimentation rates and the post-rift setting.

Cenomanian to Campanian water-loaded subsidence is $0.4-0.8 \mathrm{~km}$ for all wells in the study area. Best-fitting theoretical thermal subsidence curves indicate that stretching beneath all wells was modest $(\beta<1.5$; Figure 7$)$. Cenozoic subsidence at the northern and southern fringes of the Mauritania basin is very low (Figure 7). In contrast, wells in the center of the basin record water-loaded subsidence of up to $0.8 \mathrm{~km}$ from $23.8-0 \mathrm{Ma}\left(\sim 0.03 \mathrm{~mm} \mathrm{a}^{-1}\right)$. This subsidence pattern is a significant departure from predicted thermal subsidence patterns. Reflection data does not contain evidence of significant 
Neogene stratigraphic growth (Figure 4). The thick Neogene sedimentary pile, mapped using the seismic dataset, indicates this subsidence pattern is regional and extends $\sim 500 \mathrm{~km}$ from the center of the Mauritania basin (Figure 8). We estimate clastic sedimentation rates using the isopachs of solid sediment thickness shown in Figure 8. In the Mauritania basin solid sedimentary flux was high: $0.2_{-0.1}^{+0.2} \times 10^{3} \mathrm{~km}^{3} \mathrm{Ma}^{-1}$ between 23-5.6 Ma, and $1.9_{-1.4}^{+2.0} \times 10^{3} \mathrm{~km}^{3} \mathrm{Ma}^{-1}$ from 5.6-0 Ma. The sedimentary flux errors were calculated by propagating uncertainties in compaction parameters. A Neogene increase in clastic deposition is reported elsewhere in Africa (e.g. Paul et al., 2014).

\section{Discussion}

Cenomanian to Campanian subsidence occurred across the West African margin. Wells at the northern and southern fringe of the basin indicate that Neogene subsidence was $<50 \mathrm{~m}$ (Figure 7 ). In contrast, stratigraphy in the center of the Mauritanian basin records up to $0.8 \mathrm{~km}$ of Neogene subsidence. Interpretation of a two-dimensional seismic reflection dataset shows that Neogene subsidence occurred over an area of $\sim 250 \times 10^{3} \mathrm{~km}^{2}$ (Figure 8). Seismic data does not contain evidence of significant Neogene stratigraphic growth, which indicates that this phase of subsidence was unrelated to stretching or salt movement (Figures 1 and 4). Neogene subsidence is an order of magnitude larger than, and the opposite sign to, estimated glacio-eustasy (Figure 7; Haq et al., 1987; Miller et al., 2005).

The backstripping performed (e.g. Figure 7) assumes that the Mauritania margin has negligible elastic strength, which is consistent with Watts (1994)'s suggestion that lithosphere along parts of the northwest African margin is weak $\left(T_{e}<5 \mathrm{~km}\right)$. To assess the impact of loading by Cape Verde on subsidence of the Mauritania margin we estimated the position of maximum uplift (i.e. flexural forebulge, $x_{b}=\pi \alpha_{f}$ ), where flexural parameter, $\alpha_{f}$, is a function of elastic thickness, $T_{e}$. We assume an infinite elastic plate and that the load is concentrated at Boa Vista, $\sim 700 \mathrm{~km}$ away from the backstripped wells in the Mauritania basin. The flexural parameter is a function of flexural rigidity, $D$, thus

$$
\alpha_{f}=\left[\frac{4 D}{g\left(\rho_{m}-\rho_{w}\right)}\right]^{1 / 4}, \quad D=\frac{E T_{e}^{3}}{12\left(1-\sigma^{2}\right)}
$$


We set mantle and water densities to $\rho_{m}=3300$ and $\rho_{w}=1000 \mathrm{~kg} \mathrm{~m}^{-3}$, respectively, $g=9.81 \mathrm{~m} \mathrm{~s}^{-2}$. Young'17s modulus $E=70 \mathrm{GPa}$ and Poisson's ratio, $\sigma=0.25$ (e.g. Turcotte \& Schubert, 2002). Using Pim et al. (2008)'s estimate of $T_{e}=30 \mathrm{~km}$ from wide-angle seismic data and gravity modelling indicates that the crest of the forebulge is $230 \mathrm{~km}$ away from Cape Verde. This small circle encloses the moat of negative free-air gravity anomalies surrounding the islands at the center of the rise. If $T_{e}=60 \mathrm{~km}, x_{b}=392 \mathrm{~km}$ (cf. Wilson et al., 2013). If $T_{e}=100 \mathrm{~km}, x_{b}=574 \mathrm{~km}$. These calculations show that loading from Cape Verde could not have generated the Neogene subsidence observed $\sim 700 \mathrm{~km}$ away in the Mauritania basin (Figure 8D).

Thus, loading, salt withdrawal, thin-skinned tectonics or glacio-eustasy cannot explain the observed localized Neogene subsidence of the Mauritania basin. Instead, shear wave tomography, residual ocean-age depth measurements and long wavelength free-air gravity anomalies indicate that a gradient in sub-plate support exists from Cape Verde to Mauritania (Figure 9). Calculated excess temperatures in the asthenosphere are large enough to generate isostatic support of a few hundred meters. Note that our estimate of subplate support does not include that generated by viscous stresses (i.e. the dynamic problem). Close agreement between observed and theoretical thermal subsidence patterns and fast shear wave velocity anomalies beneath the plate indicate that sub-plate support has developed since $23 \mathrm{Ma} .{ }^{40} \mathrm{Ar} /{ }^{39} \mathrm{Ar}$ and $\mathrm{K} / \mathrm{Ar}$ dated Cenozoic volcanism indicates that growth of the Cape Verde swell has been sporadic since $\sim 26$ Ma (e.g. Mitchell et al., 1993; Holm et al., 2008; Madeira et al., 2010). Growth of the swell probably precedes onset of Neogene subsidence in the Mauritania basin by a few million years. These observations combined with a gradient in residual ocean age depth measurements and shear wave velocity anomalies indicate small-scale $(\sim 1000 \times 17200$ $\mathrm{km}$ ) upper mantle convection beneath Cape Verde and the West African margin since at least $23 \mathrm{Ma}$. Neogene infilling of accommodation space, which we suggest was created by mantle drawdown, has resulted in hydrocarbon maturation in the Mauritania basin (Vear, 2005).

Models of small-scale (e.g. edge-driven) convection often invoke plate motion as an important cause of mantle flow (e.g. Shahnas \& Pysklywec, 2004; Davies \& Rawlinson, 2014). However, that mechanism cannot explain our observations because the African plate has been relatively stationary since $\sim 30 \mathrm{Ma}$ (e.g. Burke, 1996). Instead, Neogene subsidence patterns, the history of magmatism at Cape Verde, and tomographic and isostatic modeling indicate that hot upwelling mantle and consequent asthenospheric 
flow can trigger lithospheric instabilities at the continental margin (Figure $10)$.

\section{Conclusion}

We calculate the subsidence history of the Mauritania basin, offshore West Africa, by backstripping 8 wells and mapping 53000-line-km of twodimensional seismic reflection data. Cenomanian-Campanian subsidence is observed in wells across the basin and is followed by post-rift thermal sag. Stretching factors are modest, $\beta<1.5$. In the center of the basin an additional $0.4-0.8 \mathrm{~km}$ of Neogene water-loaded subsidence is observed. The amplitude of subsidence indicates that glacio-eustasy is not responsible for generating the regional increase in accommodation space observed. The wavelength, location and amplitude of subsidence preclude loading as a viable mechanism for generating observed subsidence. Stratal geometries in seismic data intersecting wells contain little/no evidence of growth in the shallow section, which indicate that Neogene salt withdrawal or thin-skinned tectonics did not generate the observed subsidence patterns. Measured ocean-age depth residuals, calculated subsidence histories, magmatic histories and a new shear wave tomographic model suggest that upper mantle convection has generated an east-west bathymetric gradient of $\sim 1 / 300$ during the last $\sim 23 \mathrm{Ma}$ (Figure 10). Our observations are consistent with a lithospheric drip below the Mauritanian part of the West African margin that formed in response to the flow of hot asthenosphere away from the upwelling mantle beneath Cape Verde.

\section{Acknowledgements}

BHL is support by a National Environment Research Council Oil \& Gas CDT studentship. We are grateful to R. Cowan, R. Newton and colleagues at Tullow Oil Plc. and TGS for providing access to seismic and well data. IRIS Data Management Centre, and Geofon Program GFZ Potsdam were used to access seismic waveforms. Thanks are given to C. Ebinger, G. Ruempker, D. Shillington and co-investigators for early access to data not publicly available. We thank I. Bastow, V. Fernandes, N. Flament, M. Hoggard, L. Lonergan, N. Rawlinson, G. Stucky de Quay for their help and two anonymous reviewers for their constructive comments. 


\section{References}

Athy, L. F. (1930), Density, porosity, and compaction of sedimentary rocks, AAPG Bull., v. 14(1), p. 1-24.

Barnett-Moore, N., Hassan, R., Muller, R.D., Williams, S.E., Flamant, N. 2017. Dynamic topography and eustacy controlled paleogeographic evolution of northern Africa since the mid-Cretaceous, Tectonics, 36, p. 929-944, doi:10.1002/2016TC004280

Barton, P. \& Wood, R., 1984, Tectonic evolution of the North Sea basin: crustal stretching and subsidence, GJI, 79(3), p. 987-1022.

Burke, K., Gunnell, Y., 2008. The African erosion surface: A continentalscale synthesis of geomorphology, tectonics, and environmental change over the past 180 million years, Geol. Soc. Am. Memoir 201, 66 p

Cammarano, F., Goes, S., Vacher, P., Giardini, D., 2003. Inferring uppermantle temperatures from seismic velocities, Phys. Earth Planet. Int., v. 138, p. 197-222.

Chardon, D., Grimaud, J.-L., Rouby, D., Beauvaius, A., Christophoul, F., 2016. Stabilization of large drainage basins over geological time scales: Cenozoic West Africa, hot spot swell growth, and the Niger River, G-Cubed, v. 17, doi:10.1002/2015GC006169.

Christensen, N. I., 1982, Seismic velocities, in Handbook of Physical Properties of Rocks, v. 2, ed. by R. S. Carmichael, p. 57-74, CRC Press, Boca Raton, Fla.

Courtney, R. C., White, R. S., 1986. Anomalous heat flow and geoid across the Cape Verde Rise: evidence for dynamic support from a thermal plume in the mantle, Geophys. J. R. astr. Soc., v. 87, p. 815-867.

Davies, D. R., Rawlinson, N., 2014. On the origin of recent intraplate volcanism in Australia. Geology, v. 42(12), p. 1031-1034.

Fitton, J. G., James, D., Leeman, W. P., 1991. Basic Magmatism Associated With Late Cenozoic Extension in the Western United States: Compositional Variations in Space and Time. J. Geophys. Res., v. 96(B8), 13693-13711. 
Fishwick, S., 2010. Surface wave tomography: Imaging of the lithosphereasthenosphere boundary beneath central and southern Africa? Lithos, v. 120 , p. $63-73$.

Flament, N., Gurnis, M., Muller, R. D., 2013. A review of observations and models of dynamic topography. Lithosphere, v. 5(2), p. 189-210.

Förste, C., Bruinsma, S. L., Abrikosov, O., Lemoine, J.-M., Marty, J. C., Flechtner, F., Balmino, G., Barthelmes, F., Biancale, R., 2014, EIGEN-6C4 The latest combined global gravity field model including GOCE data up to degree and order 2190 of GFZ Potsdam and GRGS Toulouse. GFZ Data Services. http://doi.org/10.5880/icgem.2015.1.

Fowler, C. M. R., 2006. The Solid Earth. Cambridge University Press, 2nd Ed.

Goes, S., Armitage, J., Harmon, N., Smith, H., Huismans, R., 2012. Low seismic velocities below mid-ocean ridges: Attenuation versus melt retention. JGR, v. 117(B12403), doi:10.1029/2012JB009637.

Hartley, R. W., Allen, P. A., 1994. Interior cratonic basins of Africa: relation to continental break-up and role of mantle convection. Basin Research, v. 6(2-3), p. 95-113.

Haq, B. U., Hardenbol, J., Vail, P. R., 1987. Chronology of fluctuating sea levels since the Triassic. Science, v. 235, p.1156-1167.

Hoggard, M. J., Winterbourne, J., Czarnota, K., White, N., 2017. Oceanic residual depth measurements, the plate cooling model and global dynamic topography, JGR, doi:10.1002/2016JB013457.

Immenhauser, A., 2009. Estimating palaeo-water depth from the physical rock record, Earth-Science Review, v. 96(1-2), p. 107-139.

Jones, S. M., Lovell, B., Crosby, A. G., 2012. Comparison of modern and geological observations of dynamic support from mantle convection, J. Geol. Soc. London, v. 169, p. 745-758, doi:10.1144/jgs2011-118.

King, S. D., Ritsema, J., 2000. African Hot Spot Volcanism: Small-Scale Convection in the Upper Mantle Beneath Cratons, Science, 290, doi:10.1126 /science.290.5494.1137. 
Leckie, R. M., Olson, H. C., 2003. Foraminifera as proxies for sea-level change on siliciclastic margins, SEPM Sepc. Pub., v. 75, p. 5-19.

Levander, A., Humphreys, G., Ryan, P., (2009) Program to Investigate Convective Alboran Sea System Overturn. International Federation of Digital Seismograph Networks. Other/Seismic Network. doi:10.7914/SN/XB 2009

Lodge, A., Helffrich, G., 2006. Depleted swell root beneath the Cape Verde Islands, Geology, v. 34(6), p. 449-452.

McCarthy, C., Takei, Y., Hiraga, T., 2011. Experimental study of attenuation and dispersion over a broad frequency range: 2. The universal scaling of polycrystalline materials. J. Geophys. Res., v. 116(B09207), doi:10.1029/2011JB008384.

McKenzie, D., Roberts, J. M., Weiss, N. O., 1974. Convection in the Earth's mantle: Towards a numerical simulation, J. Fluid Mech. V. 62(3), p. $465-538$.

Miller, K. G. et al., 2005. The Phanerozoic Record of Global Sea-Level Change. Science, v. 310(5752), p. 1293-1298.

Mitchell, J. G., Le Bas, M. J., Zielonka, J., Furnes, H., 1983. On dating the magmatism of Maio, Cape Verde Islands, EPSL, v. 64, p. 61-76.

Müller, R.D., Hassan, R., Gurnis, M., Flament, N., Williams, S.E., 2017. Dynamic topography of passive continental margins and their hinterlands since the Cretaceous, Gondwana Research, http://dx.doi.org/10.1016/j.gr.2017.04.028.

Pekeris, C. L., 1935, Thermal convection in the interior of the Earth, GJI, v. 3(8), 343-367.

Pim, J., Peirce, C., Watts, A. B., Grevemeyer, I., Krabbenhoeft, A., 2008. Crustal structure and origin of the Cape Verde Rise, EPSL, v. 272, p. $422-428$.

Priestley, K., McKenzie, D., 2006. The thermal structure of the lithosphere from shear wave velocities, EPSL, v. 244, p. 285-301. 
Priestley, K., McKenzie, D., 2013. The relationship between shear wave velocity, temperature, attenuation and viscosity in the shallow part of the mantle, EPSL, v. 381, p. 78-91.

Shahnas, M. H., Pysklywec, R. N., 2004. Anomalous topography in the western Atlantic caused by edge-driven convection, GRL, v. 31(L18611), doi:10.1029/2004GL020882.

Ramalho, R., Helffrich, G., Cosca, M., Vance, D., Hoffman, D., Schmidt, D. N., 2010. Episodic swell growth inferred from variable uplift of the Cape Verde hotspot islands, Nat. Geo., doi:10.1038/NGEO982.

Richards, F. D., Hoggard, M. J., White, N., 2016. Cenozoic epeirogeny of the Indian peninsula, G-Cubed, v. 17, doi:10.1002/2016GC006545.

Rudge, J. F., Shaw Champion, M. E., White, N., McKenzie, D., Lovell, 2008. A plume model of transient uplift at the Earth'17s surface, EPSL., v. 267 , p. $146-160$.

Sandwell, D.T., R.D. Muller, W.H.F. Smith, E. Garcia, R. Francis, 2014. New global marine gravity model from CryoSat-2 and Jason-1 reveals buried tectonic structure, Science, v. 346(6205), pp. 65-67.

Sclater, J. G., P. A. F. Christie, 1980. Continental stretching: An explanation of the post-mid-Cretaceous subsidence of the central North Sea Basin, J. Geophys. Res., v. 85(B7), p. 3711-17173739, doi:10.1029/JB085iB07p03711.

Thomas, C., (2010) Morocco-Muenster. International Federation of Digital Seismograph Networks. Other/Seismic Network. doi:10.7914/SN/3D 2010.

Schaeffer, A. J., Lebedev, S., 2013. Global shear speed structure of the upper mantle and transition zone, GJI, doi:10.1093/gji/ggt095.

Takei, Y., Karasawa, F., Yamauchi, H., 2014. Temperature, grain size, and chemical controls on polycrystal anelasticity over a broad frequency range extending into the seismic range, J. Geophys. Res.: Solid Earth, v. 119, doi:10.1002/2014JB011146. 
Vear, A., 2005. Deep-water plays of the Mauritanian continental margin, In: Dore, A. G. and Vining, B. A. (eds.) Petrol. Geol.: North-West Europe and Global Perspectives, Proc. 6th Petrol. Geol. Conf., p. 1217-1232.

Vinnik, L., Silveira, G., Kiselev, S., Farra, V., Weber, M., Stutzmann, E., 2012. Cape Verde hotspot from the upper crust to the top of the lower mantle, EPSL, v. 319-320, p. 259-268.

Walford, H.L., White, N.J., Sydow, J.C., 2005. Solid sediment load history of the Zambezi Delta, Earth Planetary Science Letters, v. 218, p. 49-63.

Watts, A. B., 1994. Crustal structure, gravity anomalies and flexure of the lithosphere in the vicinity of the Canary Islands, GJI, v. 119, p. 648-666.

Wilson, D. J., Peirce, C., Watts, A. B., Grevemeyer, I., 2013. Uplift at lithospheric swells-II: is the Cape Verde mid-plate swell supported by a lithosphere of varying strength? GJI, 193(2), p. 798-819.

Wyllie, M. R. J., A. R. Gregory, and L. W. Gardner (1956), Elastic wave velocities in heterogeneous and porous media, Geophys., v. 21(1), p. 41-70, doi:10.1190/1.1438217. 


\begin{tabular}{|lllll|}
\hline & Well & WD $(\mathrm{m})$ & Cenozoic PWD & Benthonic biofacies (e.g) \\
\hline \hline A & NSO-1 & 79 & Neritic & Cibicides Lobatulus \\
\hline B & Loup De Mer-1 & 172 & Upper Bathyal & Gabonisporis Vigouroxi \\
\hline C & Labedina-1 & 1266 & Middle Bathyal & Bulmina Costata \\
\hline D & Chinguetti 4-3 & 281 & Upper Bathyal & Cibicidoides grosseperforatus \\
\hline E & Tevet-1 & 490 & Upper Bathyal & Epinoides Vicksburgensis \\
\hline F & Merou-1 & 1776 & Middle Bathyal & Bulmina Costata \\
\hline G & Tiof-4 & 1120 & Middle Bathyal & Bulmina Striata \\
\hline H & Flamant-1 & 1414 & Middle Bathyal & Cibicidoides Grimsdale \\
\hline
\end{tabular}

Table 1: Modern (WD) and palaeo-water depth (PWD) of wells on Mauritania margin (Figure 1). Example is given of benthic biofacies (e.g. foraminifera) data from well reports used to determine PWD. Neritic: 0-150 m, upper bathyal: 150-500 m, middle bathyal: 500-2000 m (Immenhauser, 2009). 

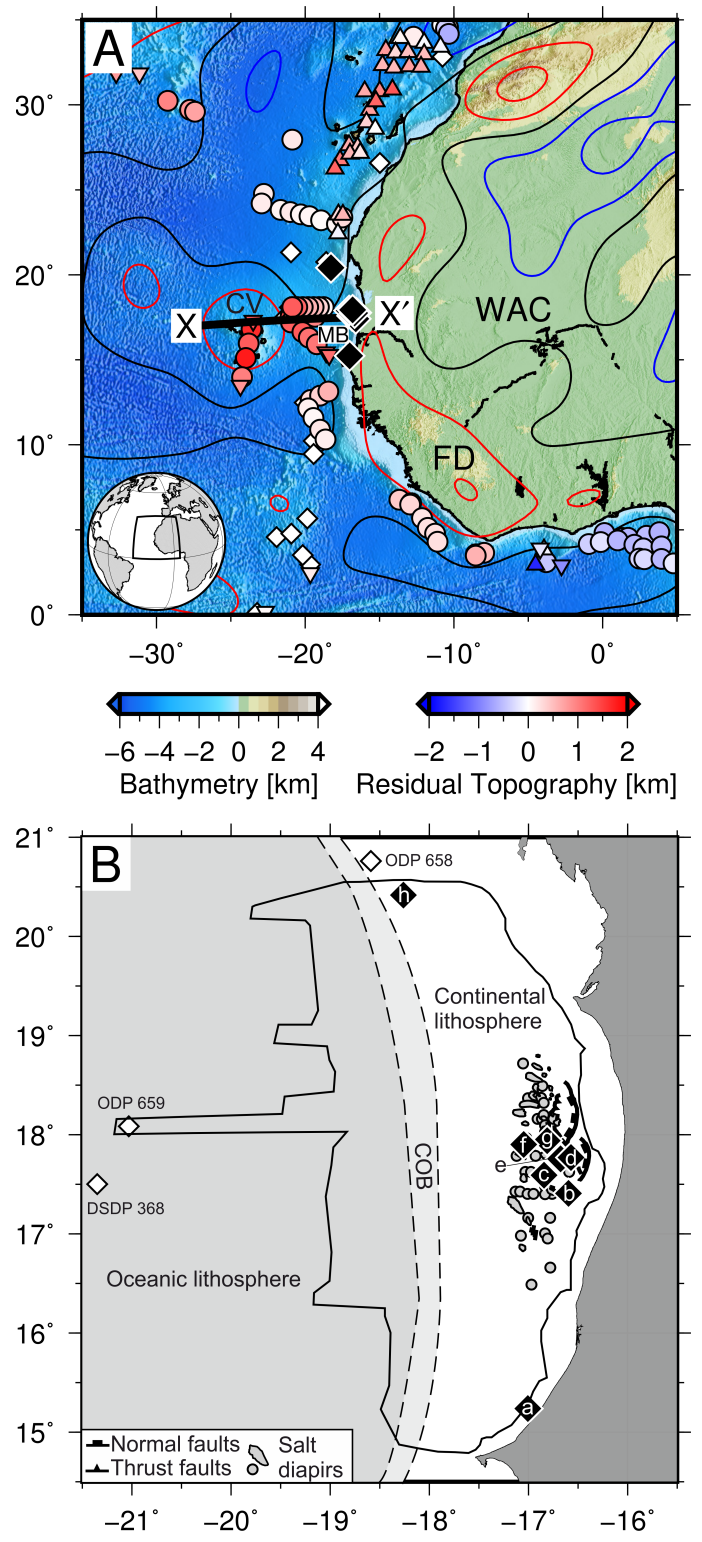

Figure 1: (A) Bathymetry of West African margin. Black polygon on inset globe = location of panel A. Red/black/blue contours = positive/zero/negative long wavelength (800-2500 $\mathrm{km}$ ) free-air gravity anomalies from GOCE dataset (Förste et al., 2014); contour interval = $10 \mathrm{mGal}$. Circles/upward/downward pointing triangles $=$ accurate $/ \mathrm{minimum} / \mathrm{maximum}$ residual ocean-age depth estimates (this study; Hoggard et al., 2017). Black/white diamonds $=$ commercial/IODP-DSDP wells. $\mathrm{X}-\mathrm{X}^{\prime}=$ cross-section shown in Figure 9. $\mathrm{CV}=$ Cape Verde Rise, $M B=$ Mauritania basin, $W A C=$ West African craton and FD = Fouta Djallon.(B) Geological map of West African margin with location of seismic data (black polygon) and wells (diamonds). Wells: $\mathrm{a}=\mathrm{NSO}-1, \mathrm{~b}=$ Loup De Mer-1, $\mathrm{c}=$ Labedina-1, $\mathrm{d}=$ Chinguetti $4-3, \mathrm{e}=$ Tevet $-1, \mathrm{f}=$ Merou- $1, \mathrm{~g}=$ Tiof- $4, \mathrm{~h}=$ Flamant- 1 . Gray polygons $=$ salt; black lines with tick marks $=$ thin-skinned normal and thrust faults. Dashed lines labeled $\mathrm{COB}=$ continent-ocean boundary. 


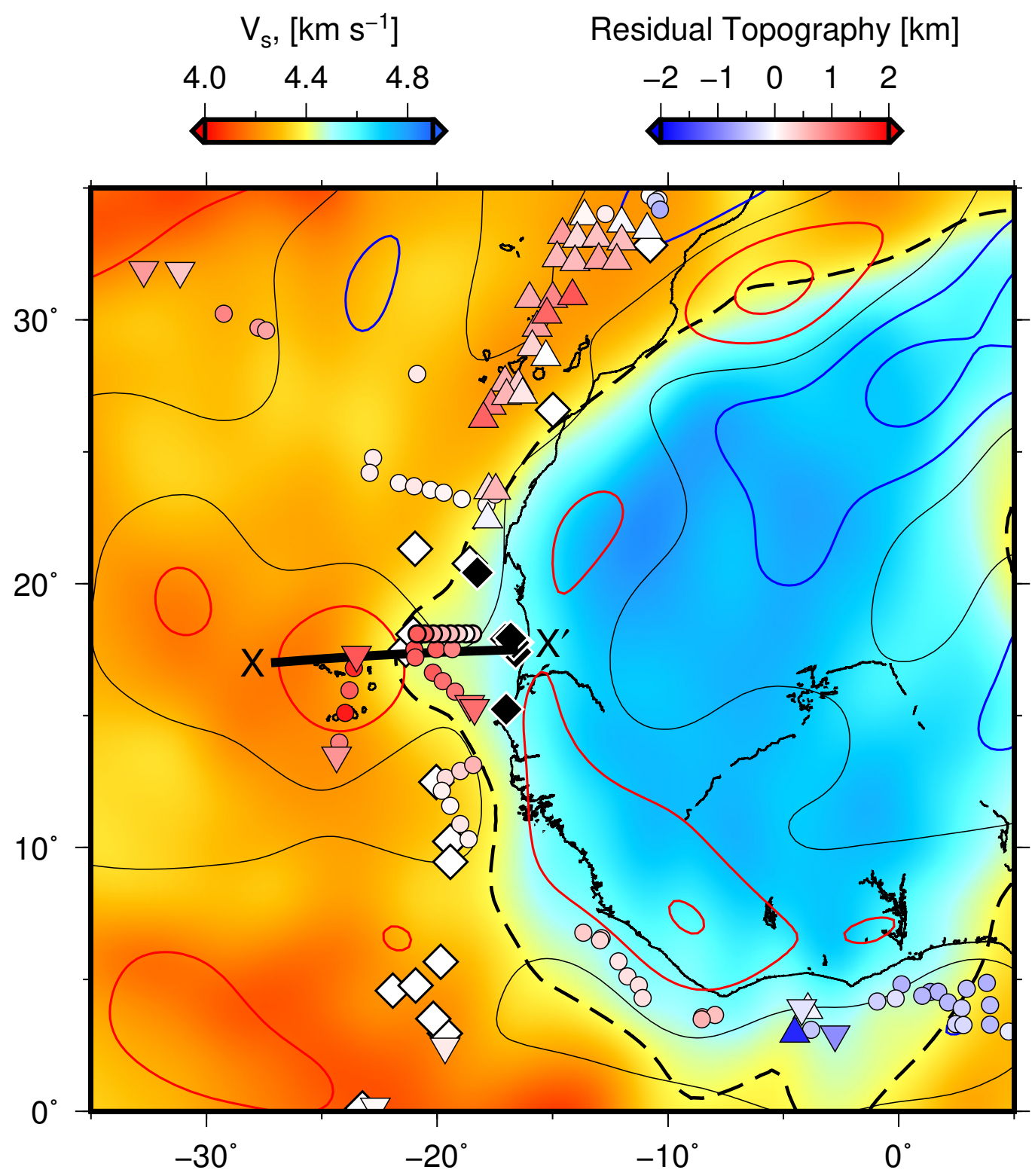

Figure 2: Slice through new shear wave tomographic model at $125 \mathrm{~km}$ depth. Color scale $=$ absolute shear wave velocities. Red/black/blue contours $=$ positive/zero/negative long wavelength $(800-17172500 \mathrm{~km})$ free-air gravity anomalies from GOCE dataset; contour interval $=10 \mathrm{mGal}$. Circles and upward/downward pointing triangles $=$ residual oceanage depth measurements and minimum/maximum estimates (this study; Hoggard et al., 2017). Black/white diamonds $=$ commercial/IODP-DSDP wells. $X-X^{\prime}=$ cross section shown in Figure 9. Dashed line encloses region of fast velocities anomalies $\left(>4.4 \mathrm{~km} \mathrm{~s}^{-1}\right)$. Note protuberance of fast velocities beneath the Mauritania basin. 

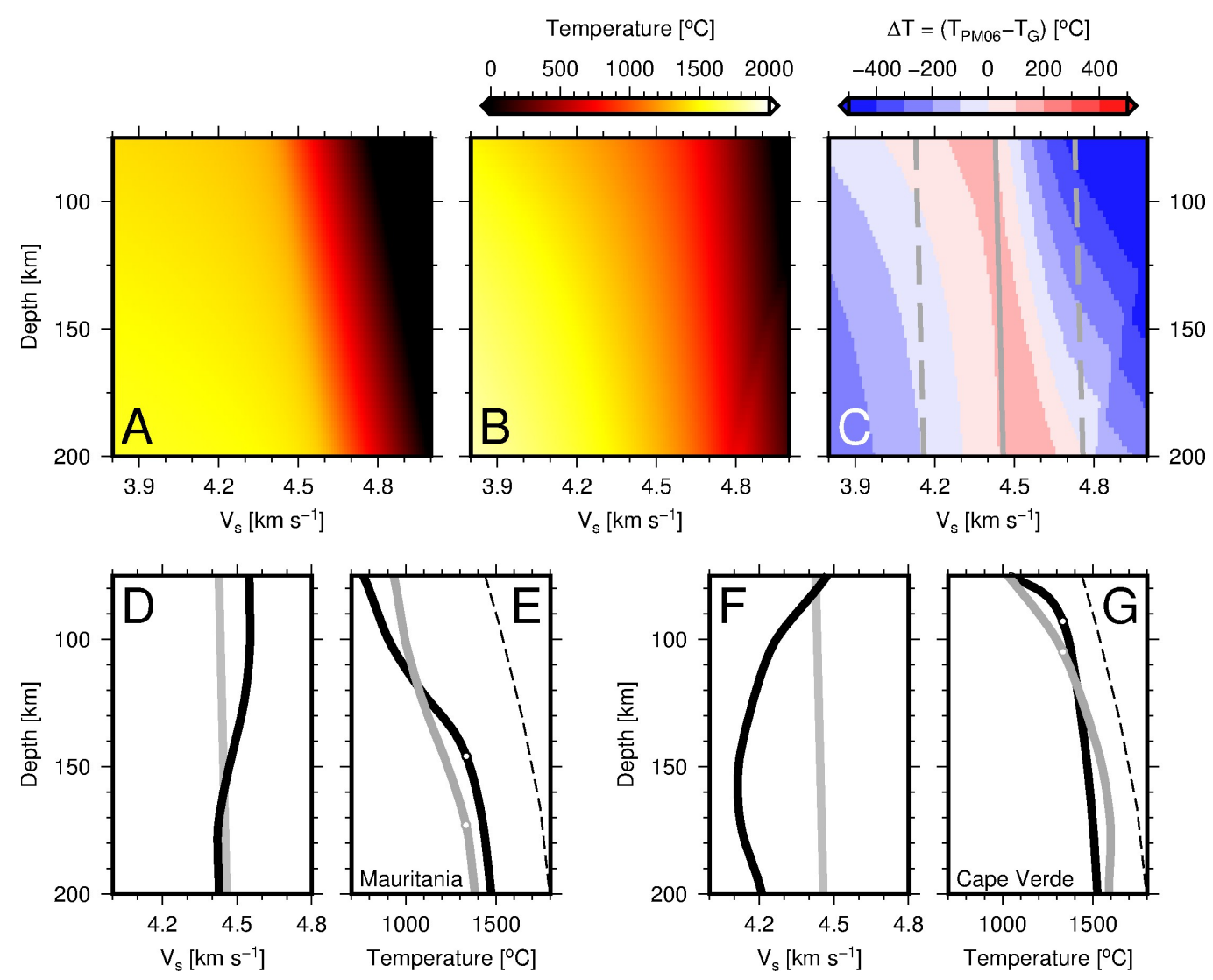

Figure 3: Look-up charts showing temperature as a function of depth and shear wave velocity $\left(V_{s}\right)$ for $(\mathrm{A})$ Priestley \& McKenzie (2006)'s empirical parametrization $\left(T_{P M 06}\right)$. (B) Goes et al. (2012)'s mineral physics parametrization with anelastic velocity correction $\left(T_{G}\right)$. (C) Difference between the two parametrizations. Gray line $=$ global average (modified AK135 from Schaeffer \& Lebedev, 2013); dashed lines = global average \pm 0.3 $\mathrm{km} \mathrm{s}^{-1}$. (D) Black curve = absolute shear wave velocities, $V_{s}$, beneath Mauritania from new tomographic model. Gray line $=$ global average. (E) $V_{s}$ converted to temperature as a function of depth using Priestley \& McKenzie (2006)'s parametrization (black line) or the Goes et al. (2012) parametrization corrected for anelasticity (gray line). Circles = $1330^{\circ} \mathrm{C}$ used to map lithosphere-asthenosphere boundary (see Figure 9). Dashed line $=$ dry peridotite solidus (Fitton et al., 1991). (F-17G) Velocities and calculated temperatures beneath the Cape Verde Rise. 

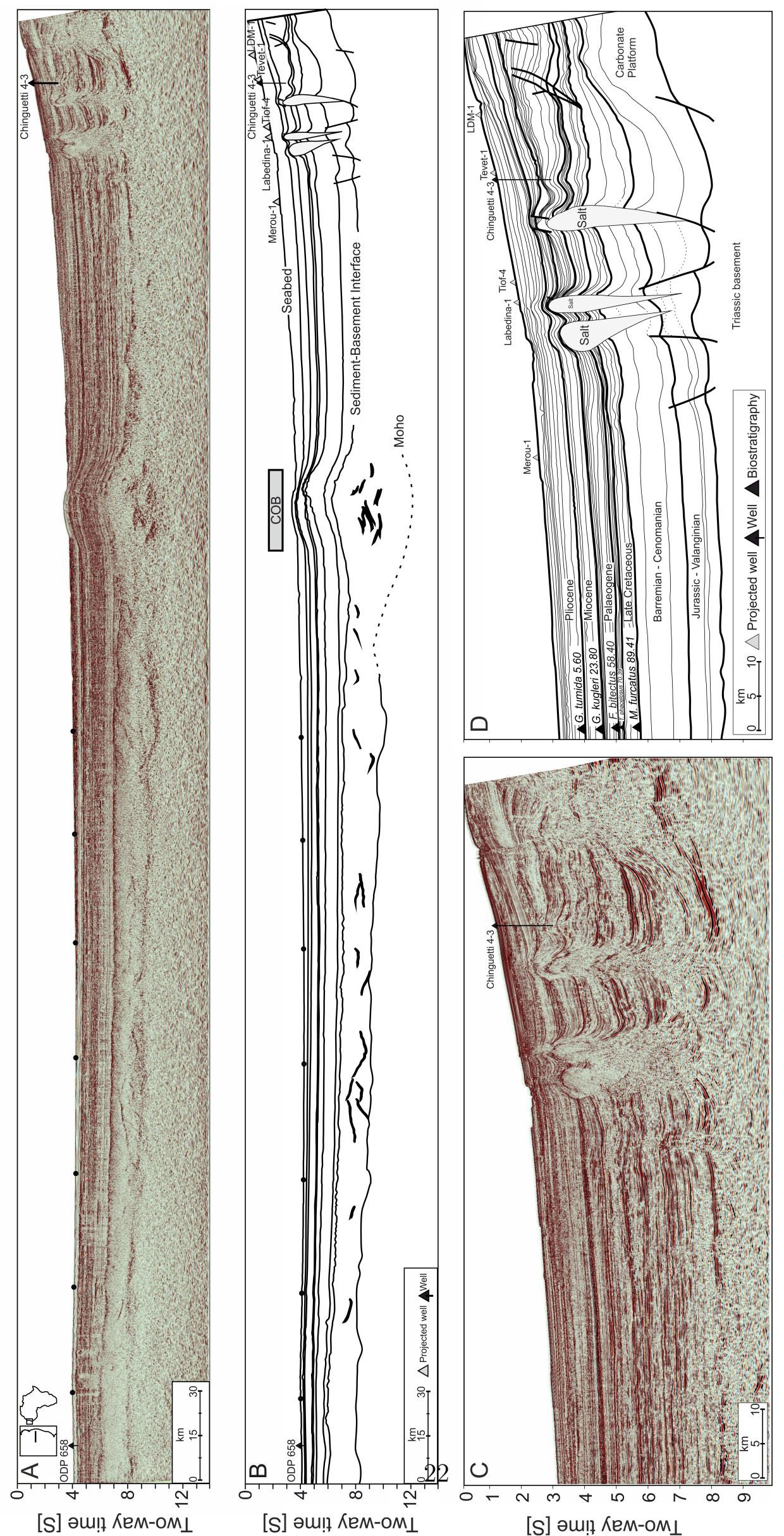

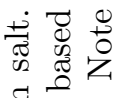

贯

స न

항

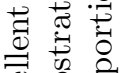

论

금

䨠

800

.

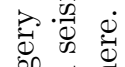

范

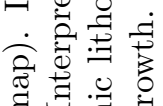

范

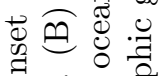

$\exists$ in

舟

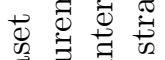

उ $5 . \exists$.

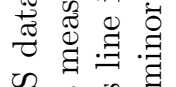

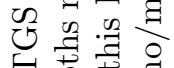

ज苦声

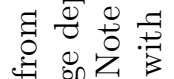

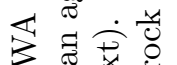

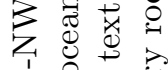

굴

ㄱํ를

象

光, 夏

: $)$ 要

记

.

W

ङ 0 ส

अ

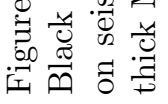

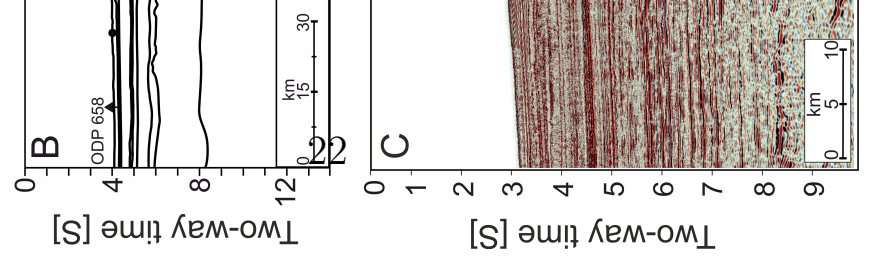



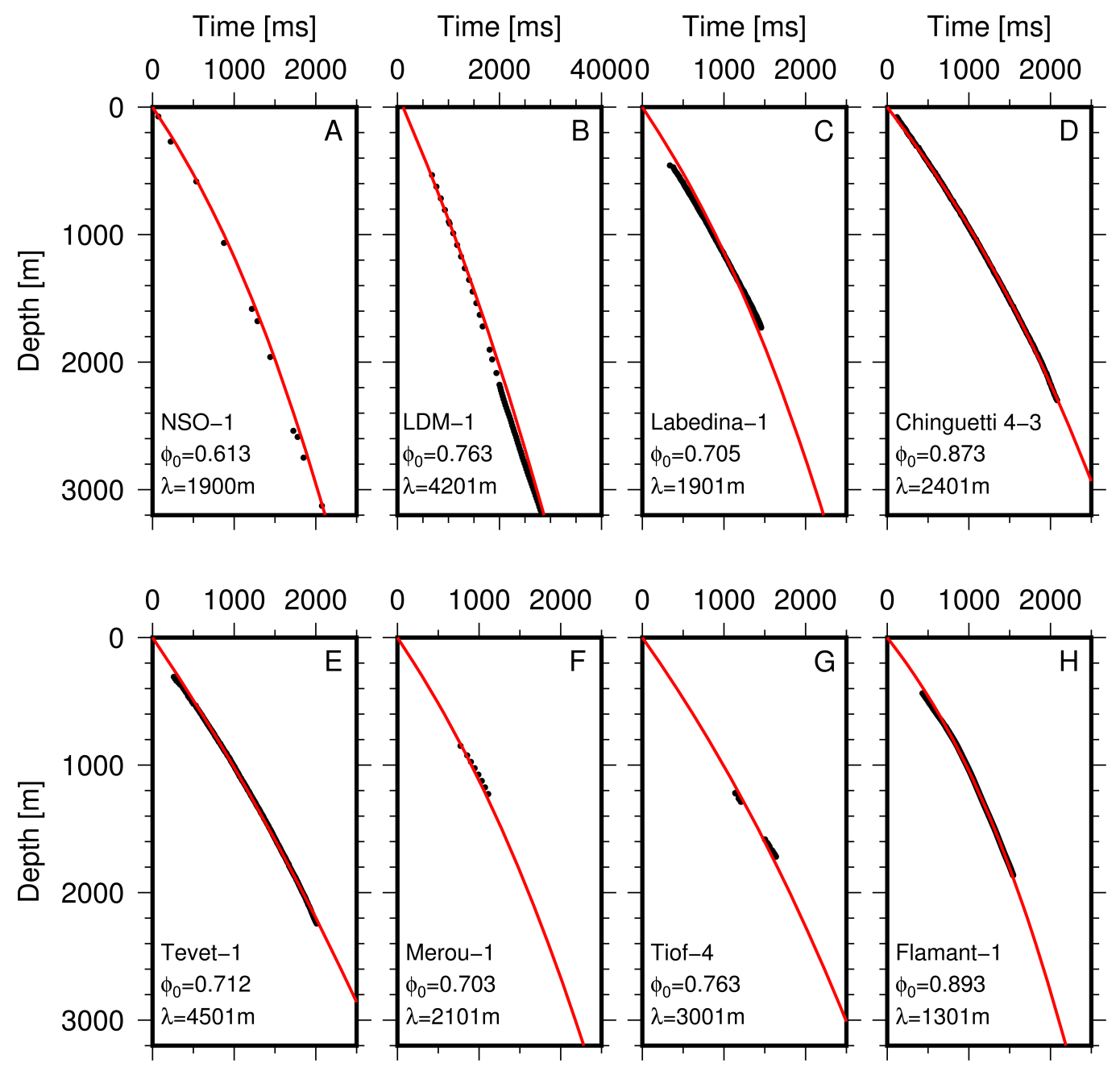

Figure 5: (A-H) Check shot data for wells on the Mauritania margin (Figure 1). Bestfitting compaction parameters (initial porosity, $\phi_{\circ}$, and compaction wavelength, $\lambda$ ) were determined by minimizing misfit between observed check shot data and calculated timedepth curves (red lines; Figure 6). 

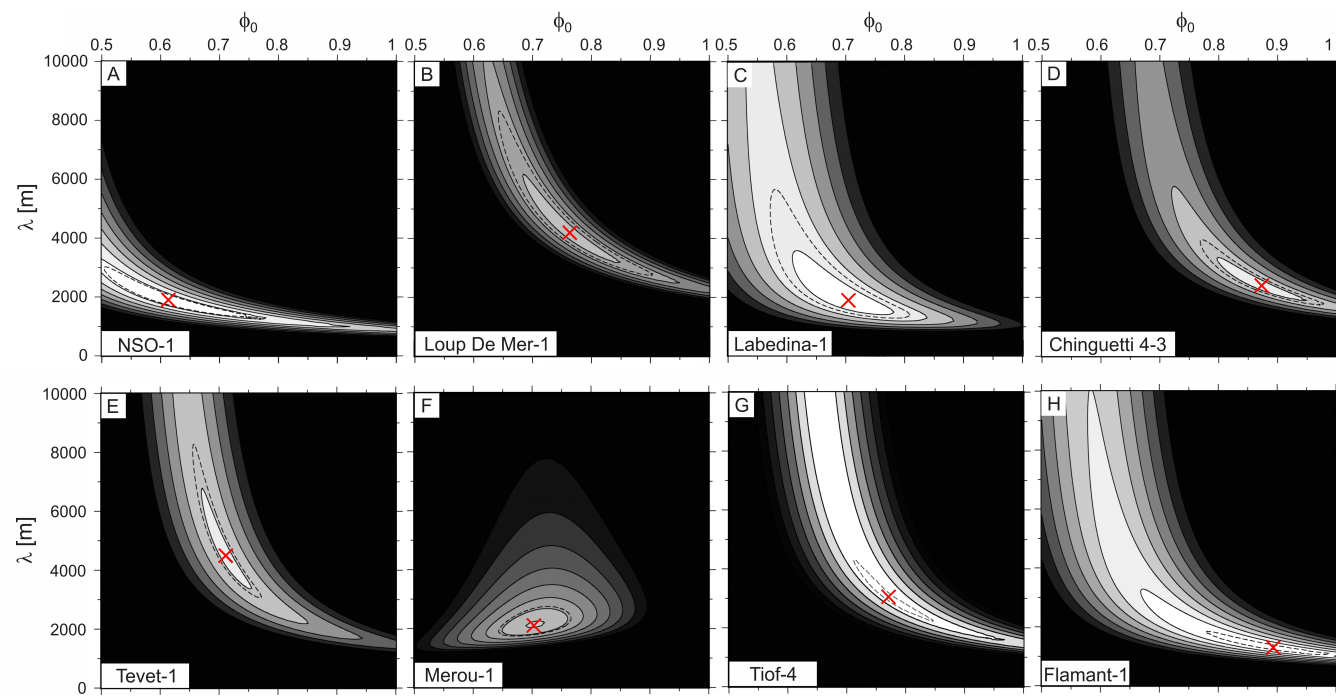

Figure 6: (A-H) Compaction parametrization. Root-mean-squared (rms) misfit between observed and calculated time-depth curves plotted as a function of initial porosity, $\phi_{\circ}$, and compaction decay length, $\lambda$. Red crosses $=$ compaction parameters with lowest residual misfit to time-depth data (Figure 5); dashed lines $=$ contours of misfit used to estimate compaction uncertainties. 


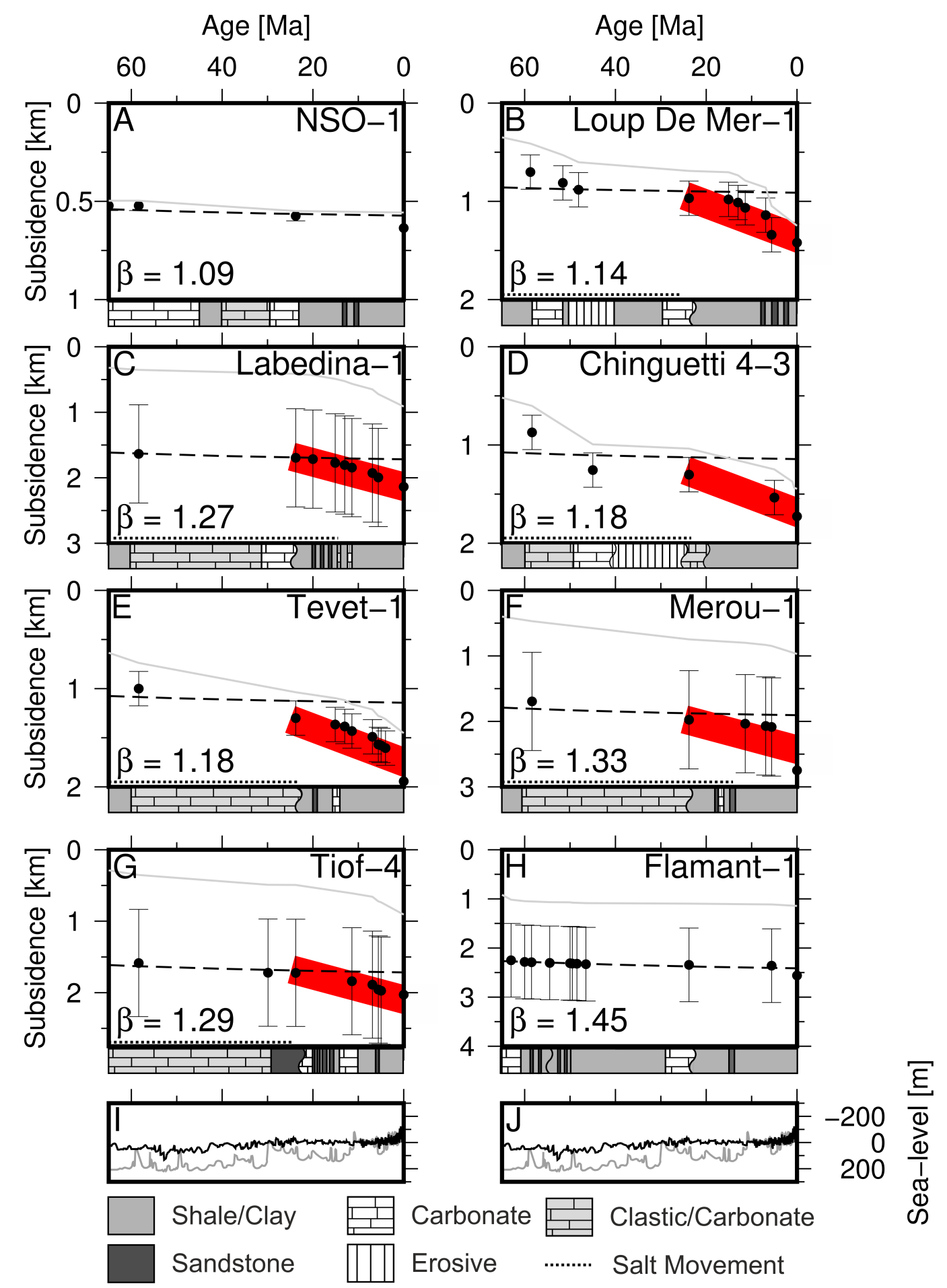

Figure 7: (A-H) Cenozoic subsidence of Mauritania margin. Solid lines = decompacted, water-loaded subsidence; line thicknesses $=$ compaction uncertainties $(<50 \mathrm{~m})$. Circles $=$ decompacted, water-loaded subsidence corrected for palaeo-water depth (error bars); dashed-lines $=$ best-fitting thermal subsidence profiles (see body text). Red lines $=$ anomalous Neogene subsidence $\left(0.03 \mathrm{~mm} \mathrm{a}^{-1}\right)$. (I-J) Gray/black curves $=\mathrm{Haq} /$ Miller eustatic curves (Haq et al., 1987; Miller et al., 2005). 


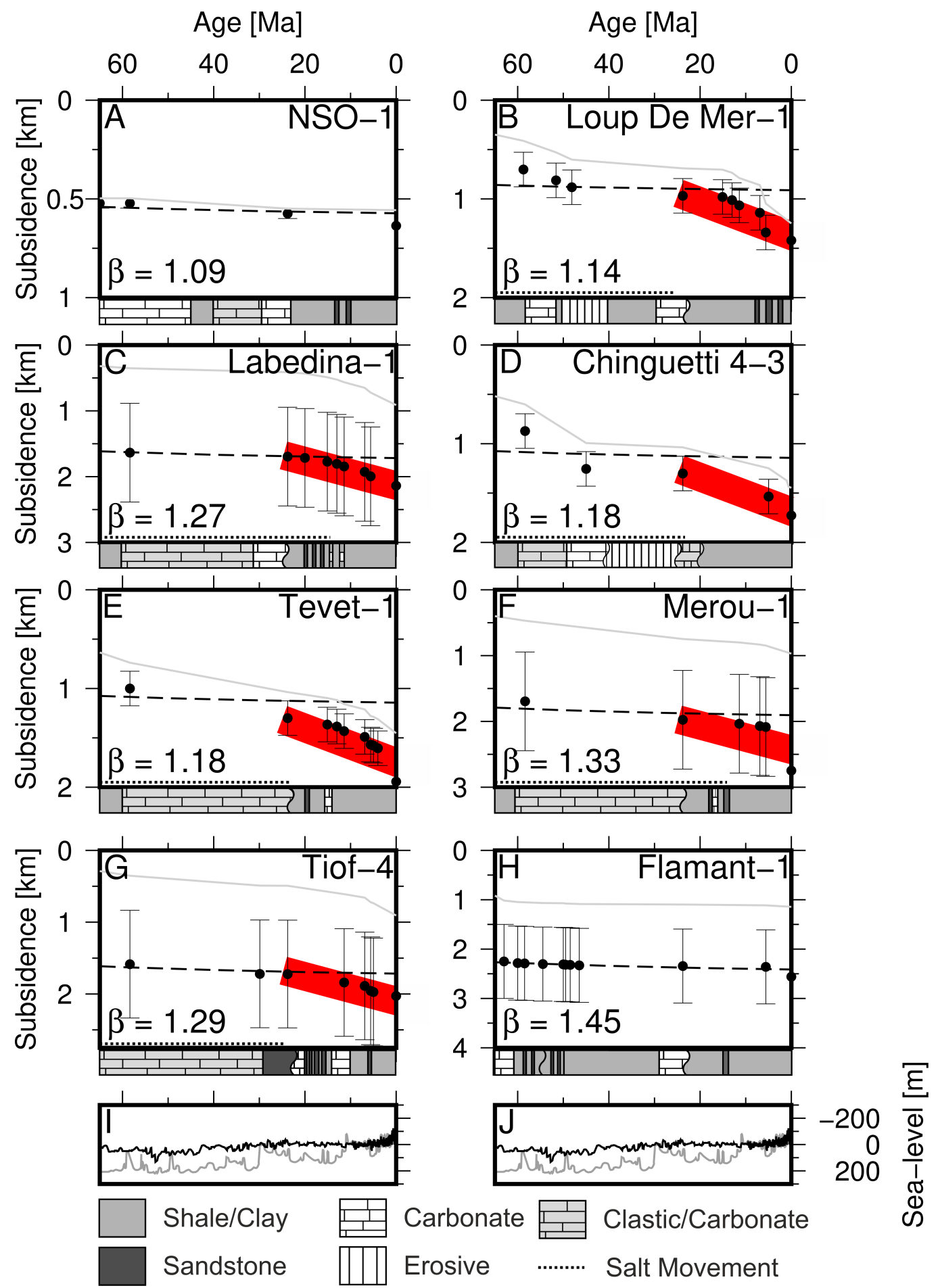

Figure 8: Neogene solid sediment thickness of Mauritania margin and flexural loading of Cape Verde. (A/B/C) Solid thickness $26^{t w e e n ~ 23.8-5.6 / 5.6-0 ~ M a / 23.8-0 ~ M a . ~(D) ~}$ Flexure of an infinite elastic plate for a point load centred on Boa Vista (solid circle). Colour scale $=$ free-air gravity data from EIGEN6c GOCE dataset (Förste et al. 2014). Dashed lines $=$ position of maximum uplift (forebulge) for $T_{e}=30 \mathrm{~km}$ or $60 \mathrm{~km}$ (cf. Pim et al., 2008; Wilson et al., 2013). Black diamonds = backstripped wells on West African margin. White diamonds = IODP \& DSDP wells. 


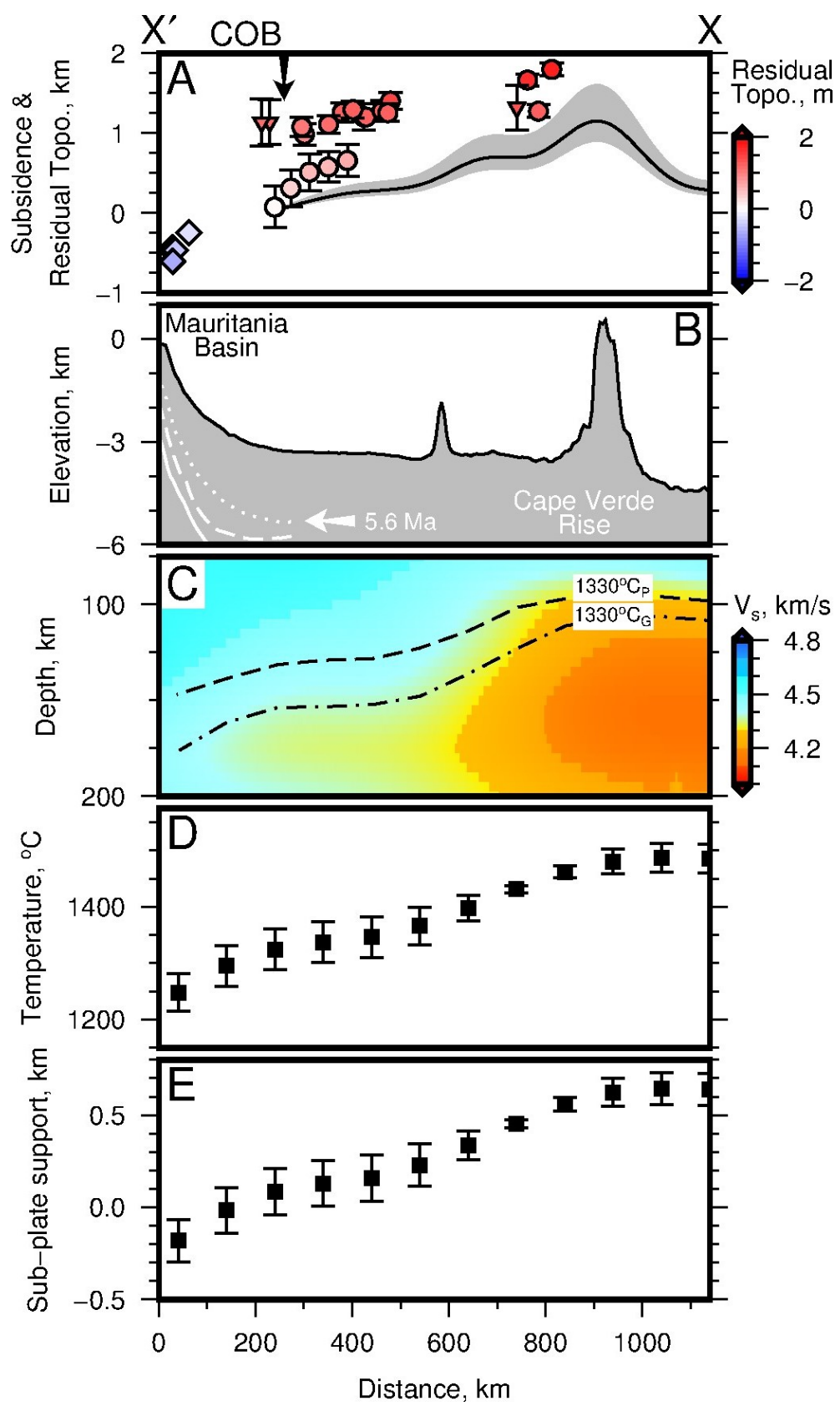

Figure 9: Summary of results along cross-section $X-X^{\prime}$ (see Figures 1 \& 2). (A) Circles and downward pointing triangles $=$ residuals from ocean-age depth projected onto line. Diamonds = Neogene-Recent (23.8-0 Ma) subsidence calculated from wells in the centre of Mauritania basin. Gray band and black line $=$ dynamic topography calculated using long wavelength $(800 \pm 2500 \mathrm{~km})$ free-air gravity anomalies from GOCE dataset and an admittance of $35 \pm 10 \mathrm{mGal} \mathrm{km}{ }^{-1}$. Arrow $=$ continent-ocean boundary $(\mathrm{COB})$ mapped using reflection seismic data. (B) Topographic swath and thickness of sedimentary rock in Mauritania basin: solid/dashed/dotted white lines $=58.4 / 23.8 / 5.6$ Ma horizons (Figure 4). (C) Surface wave tomography. Dash-dot/dash lines $=1330^{\circ} \mathrm{C}$ isotherm calculated using (P) Priestley \& McKenzie (2006)/(G) Goes et al. (2012) parametrizations. (D) Squares $=$ calculated average temperature between 100-1717200 km depth. Error bars $=$ range from $\mathrm{P}$ and $\mathrm{G}$ parametrizations. (E) Black squares = isostatic support calculated using excess temperatures (Equation 1). 


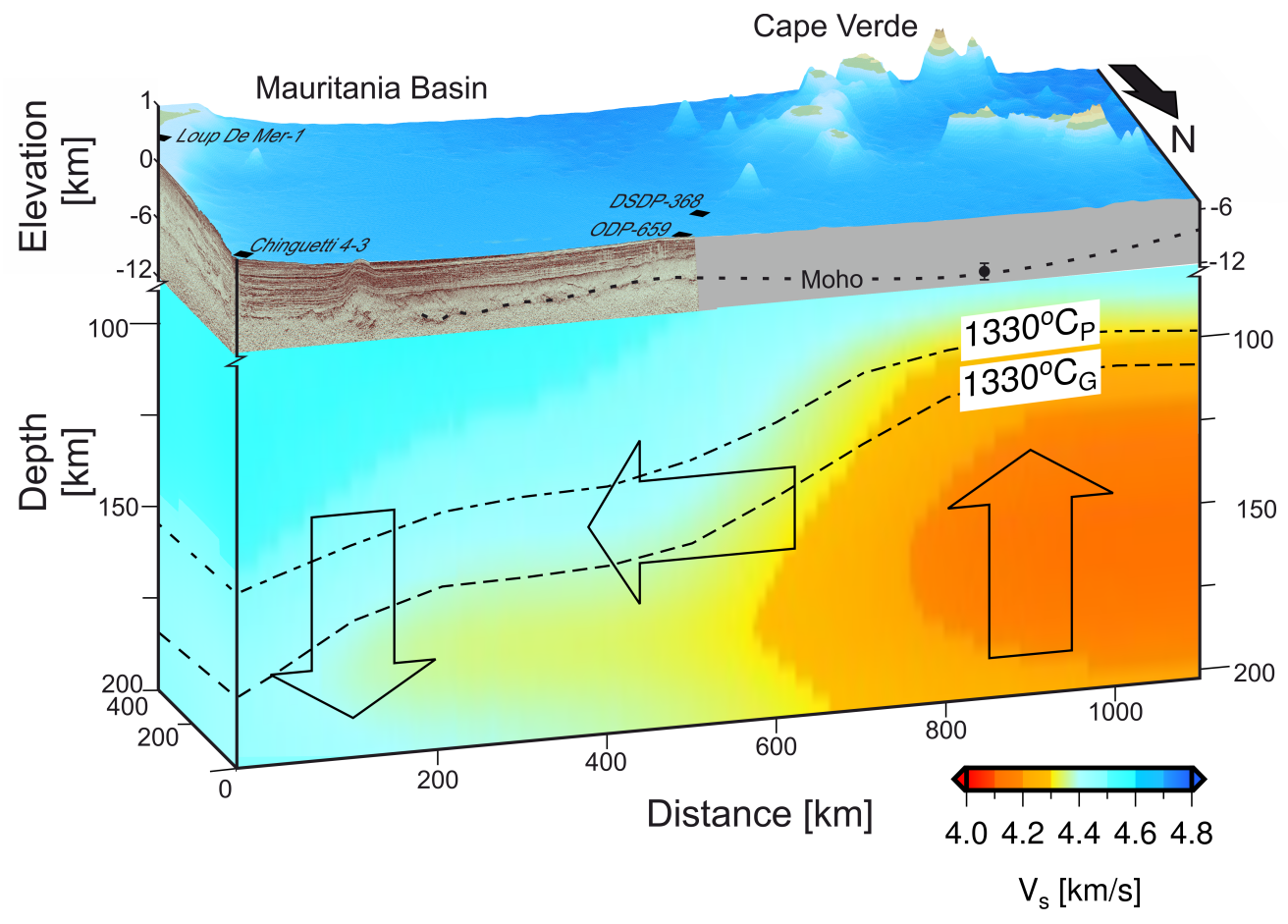

Figure 10: Cartoon summarizing results (see Figures 1 and 9 for annotation). Black circle beneath Cape Verde = Moho estimated from wide-angle seismic data (Pim et al., 2008). Arrows indicate shallow mantle flow. 


\section{Appendix A. Tomography model}

Fishwick (2010)'s surface wave tomography model was updated to incorporate data from networks throughout Africa. Inclusion of data from Mid Atlantic Ridge events recorded on the PICASSO (Levander et al., 2009) and Muenster-Morocco (Thomas, 2010) deployments provide dense path coverage across the Northwest African margin. Waveforms with low signal-to-noise ratios between periods of 50-120 s were removed from the dataset prior to inversion. Path coverage used to constrain the tomographic model is shown in Figure A.11A-B. The resolution of the tomographic model was examined at $150 \mathrm{~km}$ depth by inverting synthetic data constructed using the checkerboard velocity model shown in Supplementary Figure A.11C. Path average velocities were calculated using the inventory of African paths shown in Supplementary Figure A.11A and noise was added to the synthetic dataset commensurate with uncertainties in the real data. Supplementary Figure A.11D shows the recovered velocity structure obtained by inverting the noisy synthetic data. Importantly for our purposes, velocity perturbations of a few percent at wavelengths of $\sim 300 \mathrm{~km}$ are resolvable beneath Cape Verde and the Mauritania basin. Supplementary Figure A.12 shows the velocity model for West Africa and its surroundings. 

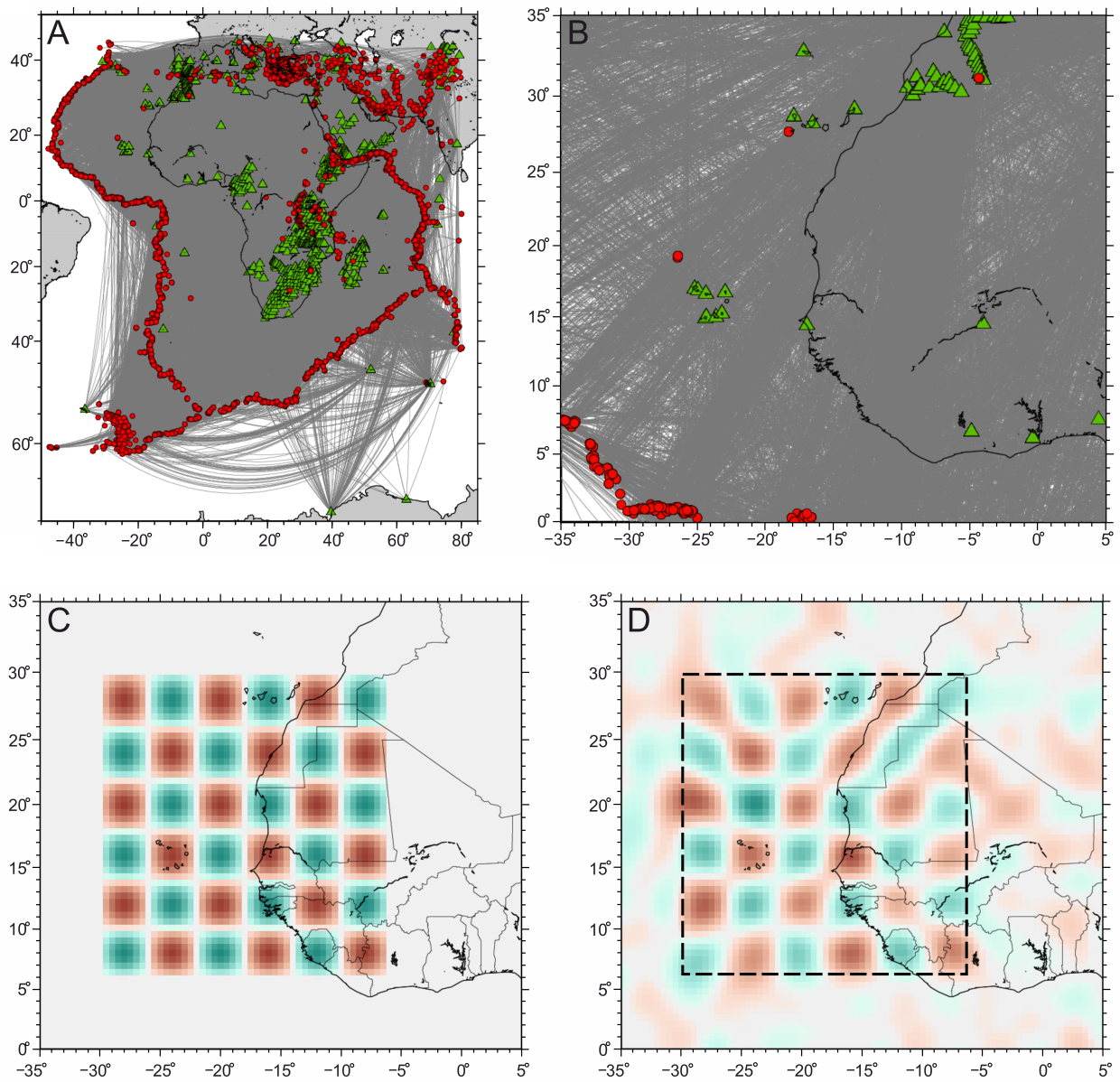

Figure A.11: (A) Path coverage (gray lines), seismic stations (triangles) and events (circles) used to constrain African tomographic model. (B) Coverage across Mauritania margin. (C-D) Recovery of synthetic velocity perturbations at $150 \mathrm{~km}$ depth. (C) Checkerboard pattern of input velocity perturbations of $\pm 6 \%$ at $4^{\circ}$ separation. (D) Recovered velocity model from inversion of synthetic data calculated using path coverage shown in panel A and noise commensurate with uncertainties in real data at $150 \mathrm{~km}$ depth. Dashed line encloses non-zero synthetic velocity perturbations in input. 

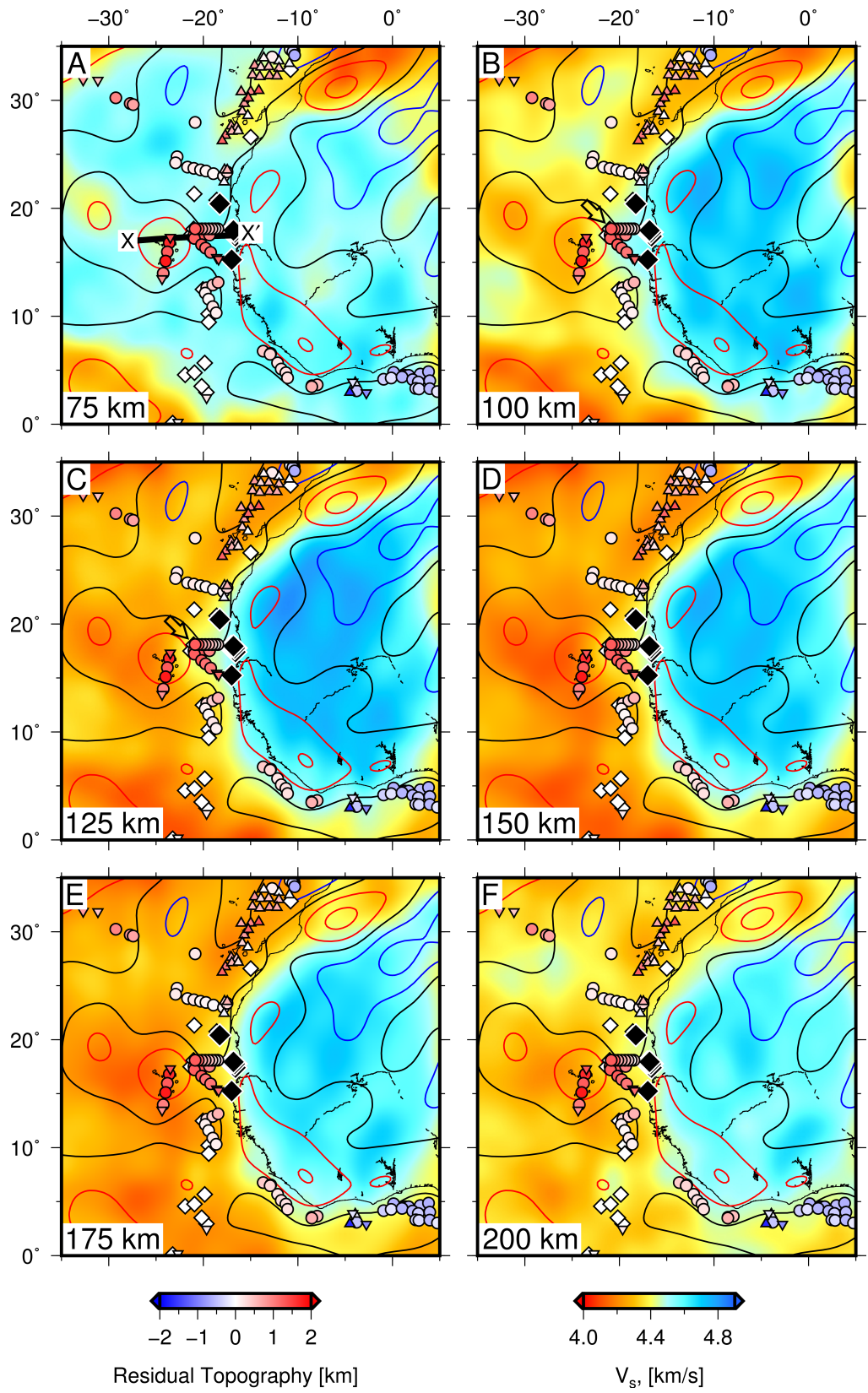

Figure A.12: Slices through new shear wave tomographic model from 75-200 km depth. Color scale $=$ absolute shear wave velocities. See Figure 2 for annotation. Note protuberance of fast velocities beneath the Mauritania basin (arrows in panels B and C). 


\section{Appendix B. Temperature from shear wave velocities}

We estimate mantle temperatures from shear waves using three techniques adapted from Priestley \& McKenzie (2006, 2013) and Goes et al. (2012).

\section{Appendix B.1. Priestley \& McKenzie (2006)}

Priestley and McKenzie (2006)'s approach uses mineral-physics based expressions, but with parameters chosen to reconcile tomographic velocities with thermal constraints from the oceanic plate cooling model and cratonic xenoliths. In their updated conversion they show that parameter values may need to vary depending the global tomographic model used (Priestley \& McKenzie, 2013). We generate a look-up table of temperatures, $T$, as a function of pressure, $P$, and shear wave velocities, $V_{s}$, using Equation 5 in Priestley \& McKenzie (2006). We assume that pressure is lithostatic (i.e. $P=\rho g z$, where $\rho=3300 \mathrm{~kg} \mathrm{~m}^{-3}$ is density, $g=9.81 \mathrm{~m} \mathrm{~s}^{-2}, z=\operatorname{depth}$ )

$$
V_{s}=\left\{1+b_{v}[z-50]\right\}\left\{m T+c+A \exp \left[-\frac{E+P V_{a}}{R(T+273.15)}\right]\right\},
$$

where $b_{v}=3.84 \times 10^{-4} \mathrm{~km}^{-1}, m=-2.8 \times 10^{-1} \mathrm{~m} \mathrm{~s}^{-1} \oint \mathrm{C}^{-1}, c=4720 \mathrm{~m}$ $\mathrm{s}^{-1}, A=-1.8 \times 10^{16} \mathrm{~m} \mathrm{~s}^{-1}$ are empirically determined constants. Activation energy $E=409 \times 10^{3} \mathrm{~J} \mathrm{~mol}^{-1}$, activation volume $V_{a}=10^{-6} \mathrm{~m}^{3} \mathrm{~mol}^{-1}$ and the gas constant $R=8.3145 \mathrm{~J} \mathrm{~mol}^{-1} \mathrm{~K}^{-1}$. Solutions to Equation (B.1) can be easily recast to extract $T\left(P(z), V_{s}\right)$.

\section{Appendix B.2. Priestley \& McKenzie (2013)}

A modified approach based on McCarthy et al. (2011)'s scaling of seismic wave frequencies, $f$, by Maxwell relaxation times, $\tau$, is given in Priestley \& McKenzie (2013). The Maxwell time scale $t=\eta / \mu$, where $\eta$ and $\mu$ are viscosity and the shear modulus, respectively. A dimensionless frequency is expressed as $f^{\prime}=f \tau$ and expressions for $V_{s}\left(f^{\prime}\right)$ can then be obtained. Priestley \& McKenzie (2013) combine this approach with an empirical parametrization similar to that in their 2006 paper. Combining their Equations 4-7, 9, 10 and 12

$$
V_{s}=\sqrt{\rho^{-1} \mu(P, T) F\left(f^{\prime}\right)},
$$

where 


$$
\begin{gathered}
\mu(P, T)=\mu_{0}+(\partial \mu / \partial T) T+(\partial \mu / \partial P) P, \\
F\left(f^{\prime}\right)=\left\{\begin{array}{lll}
\sum_{k=0}^{6} a_{k}\left(\ln f^{\prime}\right)^{k} & \text { for } f^{\prime} \leq 10^{13} \\
1 & \text { for } f^{\prime}>10^{13}
\end{array}\right.
\end{gathered}
$$

$a_{k}$ were determined empirically by McCarthy et al. (2011): $a_{0}=0.55097$, $a_{1}=0.054332, a_{2}=-0.0023615, a_{3}=-5.7175 \times 10^{-5}, a_{4}=9.9473 \times 10^{-6}$, $a_{5}=-3.4761 \times 10^{-7}, a_{6}=3.9461 \times 10^{-9}$. We tested seismic frequencies $f=$ 0.01 to $0.05 \mathrm{~Hz}$ and calculated the dimensionless frequencies using $\tau=\eta / \mu$, where $\eta=\eta_{0} / a^{\star}, a^{\star}=\exp \left[\left(E+P_{r} V_{a}\right) / R T_{r}\right] / \exp \left[\left(E+P V_{a}\right) / R T\right]$. Values for the following parameters are from their Table 1: $\mu_{0}=72.66 \times 10^{9} \mathrm{~Pa}$, $\partial \mu / \partial T=-0.871 \times 10^{7} \mathrm{~Pa}, \partial \mu / \partial P=2.04, \log _{10} \eta_{0}=22.38 \log _{10}(\mathrm{~Pa} \mathrm{~s})$, $E=402.9 \times 10^{3} \mathrm{~J} \mathrm{~mol}^{-1}, V_{a}=7.81 \times 10^{-6} \mathrm{~m}^{3} \mathrm{~mol}^{-1}, R=8.3145, T_{r}=1473$ $\mathrm{K}, P_{r}=1.5 \times 10^{9} \mathrm{~Pa}$. Note that Equations $18-22$ in their paper can also be used to determine $V_{s}(P, T)$.

We find that calculated lithospheric geotherms are similar to those from their 2006 parametrization. However, calculated sub-lithospheric temperatures are significantly greater. Takei et al. (2014)'s experimental results, which extend the frequency range of McCarthy et al. (2011)'s experiments to incorporate seismic frequencies, indicate that $T\left(V_{s}, P\right)$ determined using Priestley \& McKenzie (2013)'s results are probably too high at low wave speeds (see also Richards et al., 2016). For these reasons we use their earlier parametrization, which yields broadly similar results to Goes et al. (2012)'s approach.

Appendix B.3. Goes et al. (2012)

Goes et al. (2012)'s parametrization of $V_{s}$ was produced for a pyrolitic composition. We used an attenuation model similar to their $Q g$ and assumed a wave frequency of $0.05 \mathrm{~Hz}$. The velocity to temperature conversion includes the effects of anelasticity. $V_{s}$ is calculated as a function of temperature, pressure, composition $(X)$ and frequency

$$
V_{s}(T, P, X, f)=V_{\mathrm{anh}}(T, P, X)\left(1-\frac{Q_{g}^{-1}\left(f, T, P, C_{O H}\right)}{2 \tan (\pi \alpha / 2)}\right),
$$

where 


$$
Q_{g}\left(f, T, P, C_{O H}\right)=A_{g}\left(\frac{C_{O H}^{\mathrm{ref}}}{C_{O H}}\right)^{s} f^{\alpha} \exp \left(\frac{\alpha \gamma T_{m}}{T}\right) .
$$

${ }_{579} C_{O H}$ is hydration and $C_{O H}^{\text {ref }}$ is a reference hydration, in this case we assume ${ }_{580}$ a dry mantle, $C_{O H}^{\mathrm{ref}}=50 \mathrm{H} / 10^{6} \mathrm{Si}$. Exponent $s$ is determined empirically, ${ }_{581} A_{g}=0.1, \alpha=0.15, \gamma=38 . T_{m}$ is melting temperature; $T_{m} / T$ is the inverse 582 of the homologous temperature. Note that $\gamma T_{m}=E+P V_{a}$ (Goes et al., ${ }_{583}$ 2012). The anharmonic velocities, $V_{\text {anh }}$, are determined using Goes et al. 584 (2012)'s thermodynamic approach. These values were used to generate the 585 look-up chart shown in Figure 3b. 